\begin{tabular}{|c|c|}
\hline Title & Effects of hy poxia on principal prey and growth of flathead flounder Hippoglossoides dubius in Funka Bay, Japan \\
\hline Author(s) & Kimura, Masafumi; T akahashi, Toyomi; T akatsu, Tetsuya; Nakatani, Toshikuni; Maeda, T atsuaki \\
\hline Citation & $\begin{array}{l}\text { Fisheries Science, } 70(4), 537-545 \\
\text { https://doi.org/10.1111j.1444.2906.2004.00838.x }\end{array}$ \\
\hline Issue Date & 2004 \\
\hline Doc URL & http:/hdl.handle.net/2115/38563 \\
\hline Rights & @ 2004 公益社団法人日本水産学会; @ 2004 The Japanese Society of Fisheries Science \\
\hline Type & article \\
\hline File Information & takahashi1-51.pdf \\
\hline
\end{tabular}

Instructions for use 


\title{
Effects of hypoxia on principal prey and growth of flathead flounder Hippoglossoides dubius in Funka Bay, Japan
}

\author{
Masafumi KIMURA, ${ }^{1}$ ToYomi TAKAHASHI, ${ }^{1 *}$ Tetsuya TAKATSU, ${ }^{1}$ ToshikUni NAKATANI ${ }^{1}$ AND \\ TATSUAKI MAEDA ${ }^{2}$ \\ ${ }^{1}$ Graduate School of Fisheries Sciences, Hokkaido University, Hakodate, Hokkaido 041-8611 and \\ ${ }^{2}$ Hokusui Society Foundation, Sapporo, Hokkaido 060-0003, Japan
}

\begin{abstract}
Effects of hypoxia on the principal prey and growth of flathead flounder Hippoglossoides dubius were studied in Funka Bay. Of the three dominant year-classes that occurred in recent years, the 1995 year-class was small in total length at age $\geq 3$ and low in condition factor at age $\geq 2$. Ophiuroids (almost Ophiura sarsi), which were the dominant prey in the 1980s, were of little importance and instead, crustaceans such as mysids, natant decapods and pelagic amphipods, bivalves and fish were important prey items for $\mathrm{H}$. dubius in 2000-2001. In addition, the feeding intensity of H. dubius in 2000-2001 was lower than that in the 1980s. These facts are closely related to a reduction of prey abundance, particularly ophiuroids. It seems that the hypoxia that occurred in the central part of the bay during the summer and autumn of 1995-1997 caused the poor food supply and low growth rate at ages $2-4$ of the 1995 year-class.
\end{abstract}

KEYWORDS: condition factor, feeding, flathead flounder, Funka Bay, growth, Hippoglossoides dubius, hypoxia, ophiuroids.

\section{INTRODUCTION}

Hypoxic events affect the existence of many sea animals seriously. ${ }^{1-3}$ Many studies have been conducted on the survival times of marine benthos under hypoxic conditions (e.g. Vetter et al. ${ }^{4}$ ). In recent years, the effects of hypoxia on growth, feeding and metabolism have been reported by several authors, for example in fish, Atlantic cod Gadus morhua, ${ }^{5}$ mudskippers Boleophthalmus boddaerti and Periophthalmodon schlosser ${ }^{6,7}$ and sole Solea solea, ${ }^{8,9}$ and also in ophiuroid Amphiura filiformis, $^{10,11}$ bivalves Crassostrea virginica ${ }^{12}$ and Mytilus edulis, ${ }^{13}$ white shrimp Penaeus setiferus ${ }^{14}$ and polychaete Capitella sp..$^{15}$ These studies are based upon only the results of the laboratory experiments.

Some field studies (e.g. Imabayashi, ${ }^{16}$ Kikuchi, ${ }^{17}$ Pearson et al. ${ }^{18}$ Josefson and Widbom, ${ }^{19}$ Furota $^{20}$ ) demonstrated the reductions of biomass and abundance in benthos assemblages in the areas with low oxygen concentrations. As for fish, Pihl, ${ }^{21}$

${ }^{*}$ Corresponding author: Tel: 81-138-40-8820.

Fax: 81-138-40-8822. Email: t-tkhs@fish.hokudai.ac.jp

Received 16 September 2003. Accepted 13 February 2004.
Pihl et al. ${ }^{22,23}$ and Baden et al. ${ }^{24}$ reported that some demersal fish species left the areas with low oxygen concentrations and changed diet. However, there are few studies on a change in growth caused by reduced oxygen concentration. ${ }^{3}$

In Funka Bay, Hokkaido, bottom water with an oxygen concentration of $\leq 1.5 \mathrm{~mL} / \mathrm{L}$ had not been observed until the $1980 \mathrm{~s}^{25,26}$ However, severe hypoxia (0.6-1.1 mL/L) occurred in the central part of the bay during the summer and autumn of 1995$1997,{ }^{27}$ and the abundances of flathead flounder Hippoglossoides dubius and coonstripe shrimp Pandalus hypsinotus decreased drastically in the hypoxic area. ${ }^{28}$

Hippoglossoides dubius is the main component in the demersal fish community and is an important fishery resource in Funka Bay. For this reason, many investigations have been conducted on distribution and annual life cycle, ${ }^{29-31}$ food habits, ${ }^{32,33}$ age and growth, ${ }^{34}$ food organisms ${ }^{33,35}$ and annual change in year-class strength. ${ }^{36}$ However, no information is available on the effects of hypoxia on the biological production of $H$. dubius. The purpose of the present paper is to estimate the effects of a hypoxic event on the principal prey and growth of H. dubius in Funka Bay. 


\section{MATERIALS AND METHODS}

\section{Study area}

Funka Bay is located at the south-western part of Hokkaido, and is a semi-enclosed inner bay with a basin with a maximum depth of $96 \mathrm{~m}$ (Fig. 1). The characteristics of hydrographic conditions are as follows: in spring, the Oyashio Coastal Water (1$3^{\circ} \mathrm{C}, 33.0-33.3 \%$ ) flows into the bay and stagnates during summer. The intrusion of the Tsugaru Warm Water $\left(\geq 6^{\circ} \mathrm{C}, \geq 33.8 \%\right.$ o) occurs in autumn and stagnates during winter. The annual bottom water temperatures in the basin range from $2{ }^{\circ} \mathrm{C}$ to $10^{\circ} \mathrm{C} .^{36-39}$ The silt $(\mathrm{Md} \Phi \geq 6)$ accumulates in the greater part of the bay and the distribution of sand-gravel is limited to off Muroran. ${ }^{40}$ In recent years, the progress of eutrophication in the central part of the bay has been suggested. ${ }^{41}$

\section{Sampling and data analysis}

Samplings were conducted using R/V Ushio-Maru of Faculty of Fisheries, Hokkaido University in the daytime (09:00-16:30) from August 1993 to November 2001 in Funka Bay (Table 1; Fig. 1). Hippoglossoides dubius were collected with a $24-\mathrm{m}$ otter trawl net (cod end liner of $12 \mathrm{~mm}$ mesh). The trawl net was towed at speeds of approximately 3 knots for $15 \mathrm{~min}$ on the sea bottom at each sampling station. Collections of benthic invertebrates were conducted with a sledge net using a $1-\mathrm{m} \times 1.5-\mathrm{m}$ frame (cod end mesh of $3 \mathrm{~mm}$ ) in June and October-November 2000 and May 2001. The sledge net was towed at speeds of approximately 2 knots for $1.5-5$ min on the sea bottom. The samples were washed onto a $3-\mathrm{mm}$ aperture sieve screen on the ship, and retained fractions were fixed in $10 \%$ buffered formalin seawater. After August 2000 the water samples at approximately $0.3 \mathrm{~m}$ above the

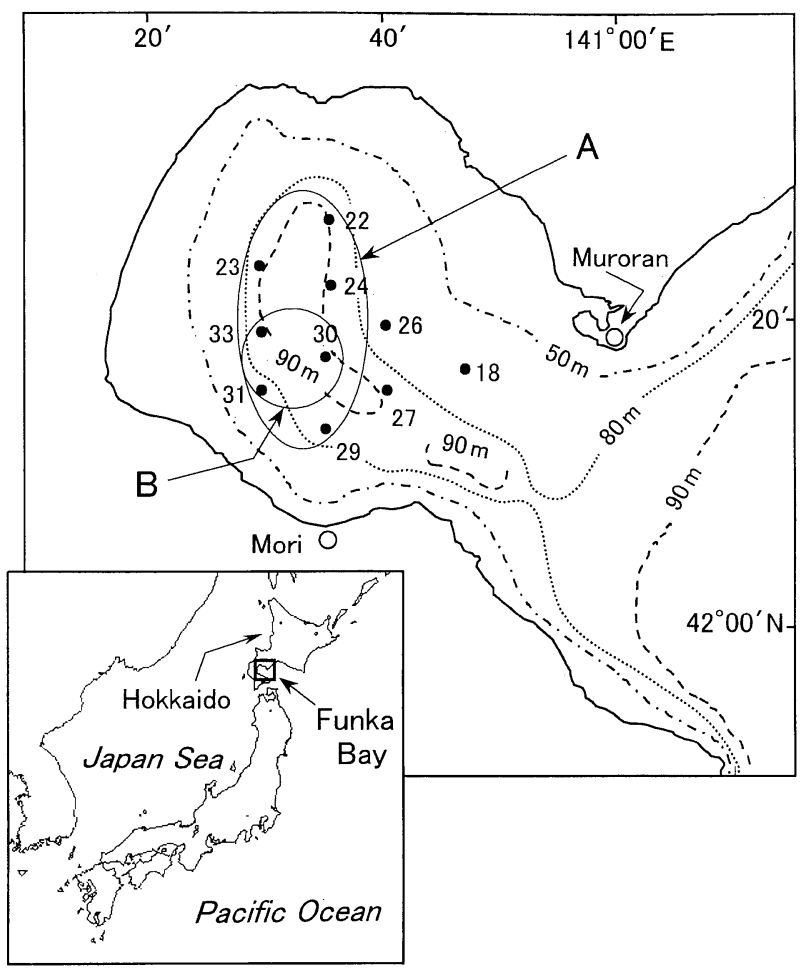

Fig. 1 Sampling sites and contours of depth in Funka Bay. (๑) Sledge net towing station; A, area for investigating growth and condition factor; $\mathrm{B}$, area for investigating food habits. Numerals denote station number.

Table 1 Samples of Hippoglossoides dubius and benthic invertebrates

\begin{tabular}{|c|c|c|c|}
\hline \multirow[b]{2}{*}{ Sampling date } & \multicolumn{2}{|c|}{ H. dubius ${ }^{\dagger}$} & \multirow{2}{*}{$\begin{array}{c}\text { Benthic invertebrates }^{\ddagger} \\
\text { Station no. }\end{array}$} \\
\hline & Station no. & No. fish & \\
\hline 31 Aug.-2 Sep. 1993 & 22,30 & 263 & \\
\hline 3-5 Oct. 1994 & 29,30 & 277 & \\
\hline 29-30 Aug. 1995 & 29,30 & 245 & \\
\hline 26-28 Aug. 1996 & $23,24,29,30,31$ & 606 & \\
\hline 27-28 Aug. 1997 & $23,24,29,30,31$ & 1051 & \\
\hline 26-27 Aug. 1998 & $24,29,30,31$ & 525 & \\
\hline 1 Sep. 1999 & 29,30 & 267 & \\
\hline $29-30$ June 2000 & - & 0 & $18,24,26,27,29,30,31,33$ \\
\hline 22-24 Aug. 2000 & $24,29,30,31,33$ & 783 & \\
\hline 17 Oct.-2 Nov. 2000 & $24,30,31,33$ & 233 & $18,24,26,27,29,30,31,33$ \\
\hline 12-14 Mar. 2001 & 30,33 & 257 & \\
\hline 28-30 May 2001 & 30,33 & 260 & $18,23,24,26,27,29,30,31,33$ \\
\hline 31 Oct.-2 Nov. 2001 & $24,30,31,33$ & 930 & \\
\hline
\end{tabular}

'Sampled with an otter trawl net.

${ }^{\ddagger}$ Sampled with a sledge net. 
sea bottom were collected using a Van-Dorn bottle $(6.8 \mathrm{~L})$, and the dissolved oxygen concentration was measured by the Winkler method.

In the laboratory, $H$.dubius were sexed and recorded along with total length $(\mathrm{mm})$, wet body weight and gonad weight (nearest $0.1 \mathrm{~g}$ ) after thawing. The age was determined from the annuli of otolith, according to Nakatani et al. ${ }^{34}$ Stomachs of H. dubius collected from August 2000 to May 2001 were excised and preserved in $10 \%$ buffered formalin solution. All food organisms in the stomachs and sledge net samples were identified to the lowest taxon possible, counted and wet weighed (nearest $0.01 \mathrm{~g}$ ). For comparison of data by fish sizes, we divided the sampled $H$. dubius into four length groups: $\leq 200 \mathrm{~mm}, 201-250 \mathrm{~mm}, 251-300 \mathrm{~mm}$ and $\geq 301 \mathrm{~mm}$ total length. Diets were analyzed in terms of numerical composition $(\% N)$, weight composition $(\% W)$ and frequency of occurrence $(\% F)$ :

$$
\begin{gathered}
\% N_{i}=n_{i} \times 10^{2} / \sum_{i=1}^{n} n_{i} \\
\% W_{i}=w_{i} \times 10^{2} / \sum_{i=1}^{n} w_{i} \\
\% F_{i}=f_{i} \times 10^{2} / \sum_{i=1}^{n} f_{i}
\end{gathered}
$$

where $n$ is the total number of prey items found in a unit, $n_{i}$ and $w_{i}$ are the number and total wet weight of prey items $i$ in a unit, respectively, and $f_{i}$ is the number of $H$.dubius stomachs containing prey items $i$ in a unit. Based on these indices, the percentage of index of relative importance $(\% I R I)^{42,43}$ was calculated for each prey item as follows:

$$
\begin{aligned}
I R I_{i} & =\left(\% N_{i}+\% W_{i}\right) \times \% F_{i} \\
\% I R I_{i} & =I R I_{i} \times 10^{2} / \sum_{i=1}^{n} I R I_{i}
\end{aligned}
$$

Because the body weight of $H$.dubius is approximately proportional to the third power of total length in both sexes, ${ }^{31}$ Fulton's condition factor $(K)$ was calculated to estimate the nutritive conditions. The feeding intensity was estimated from stomach contents index $(S C I)$ :

$$
\begin{gathered}
K=B W \times 10^{5} / T L^{3} \\
S C I=S C W \times 10^{2} / B W
\end{gathered}
$$

where $T L$ is the total length ( $\mathrm{mm}), B W$ is the body weight (g) and SCW is the stomach contents weight (g). The $K$ was calculated for the samples collected from late August to early September in each year. Gonads of male and female $H$. dubius during this period were approximately $<1 \%$ of the body weight. The diet composition and feeding intensity were examined for the samples taken from the cen- tral part of the bay where hypoxia occurred in 1995-1997, and TL and K were examined for the samples from more extensive areas (Fig. 1). To compare the growths of each year-class the samples collected chiefly from late August to early September were used. Although in 1994 and 2001 the samples collected in early October and late October-early November were used, respectively, no correction was conducted.

One-way ANOVA was used to test for significant differences in TL and $\mathrm{K}$ among year-classes. When a significant difference was found among three year-classes, multiple comparisons were made between two year-classes by Scheffe's test. Temporal and spatial changes in prey abundance were determined through a two-way ANOvA. Prey abundance data were log-transformed $[(\log (x+1)]$ prior to analysis.

\section{RESULTS}

The majority (89\%) of $5697 \mathrm{H}$. dubius collected from 1993 to 2001 were composed of three yearclasses (1989, 1991 and 1995). The mean TL values of the 1995 year-class were significantly smaller than those of the 1989 and 1991 year-classes at ages $2-6$ in both sexes $(P<0.01$ in all cases; Fig. 2$)$. However, its difference was approximately constant after age 4 . Conversely, the mean TL values at age 2 of the 1995 year-class were significantly larger than those of the 1991 year-class $(P<0.05$ for male, $P<0.001$ for female). The mean condition factors (K-value) of the 1995 year-class were significantly lower than those of the other two yearclasses at ages $2-5$ in both sexes $(P<0.01$ in all cases; Fig. 3).

The diet compositions of $H$. dubius collected from August 2000 to May 2001 are shown in Fig. 4. The principal prey items of fish $\leq 200 \mathrm{~mm}$ TL were mysids (49-84\%, almost all were Neomysis czerniawskii) in August, October and March, and ophiuroids $(61 \%$, almost all were Ophiura sarsi) in May. The diet composition of fish $\geq 201 \mathrm{~mm}$ TL varied among months, and the principal prey items were natant decapods (chiefly Eualus macilenta), fish (chiefly prickleback Anisarchus macrops and young walleye pollock Theragra chalcogramma), a bivalve Portlandia japonica and a pelagic amphipod Themisto japonica. The \%IRI of fish and $P$. japonica tended to increase with the size of $H$. dubius. The SCI was very low from August 2000 to May 2001 in both sexes (median value: 0-0.23 for male, 0-0.17 for female; Fig. 5).

Figure 6 shows the horizontal distributions of Ophiura spp., P. japonica and natant decapods from June 2000 to May 2001. The abundance of 


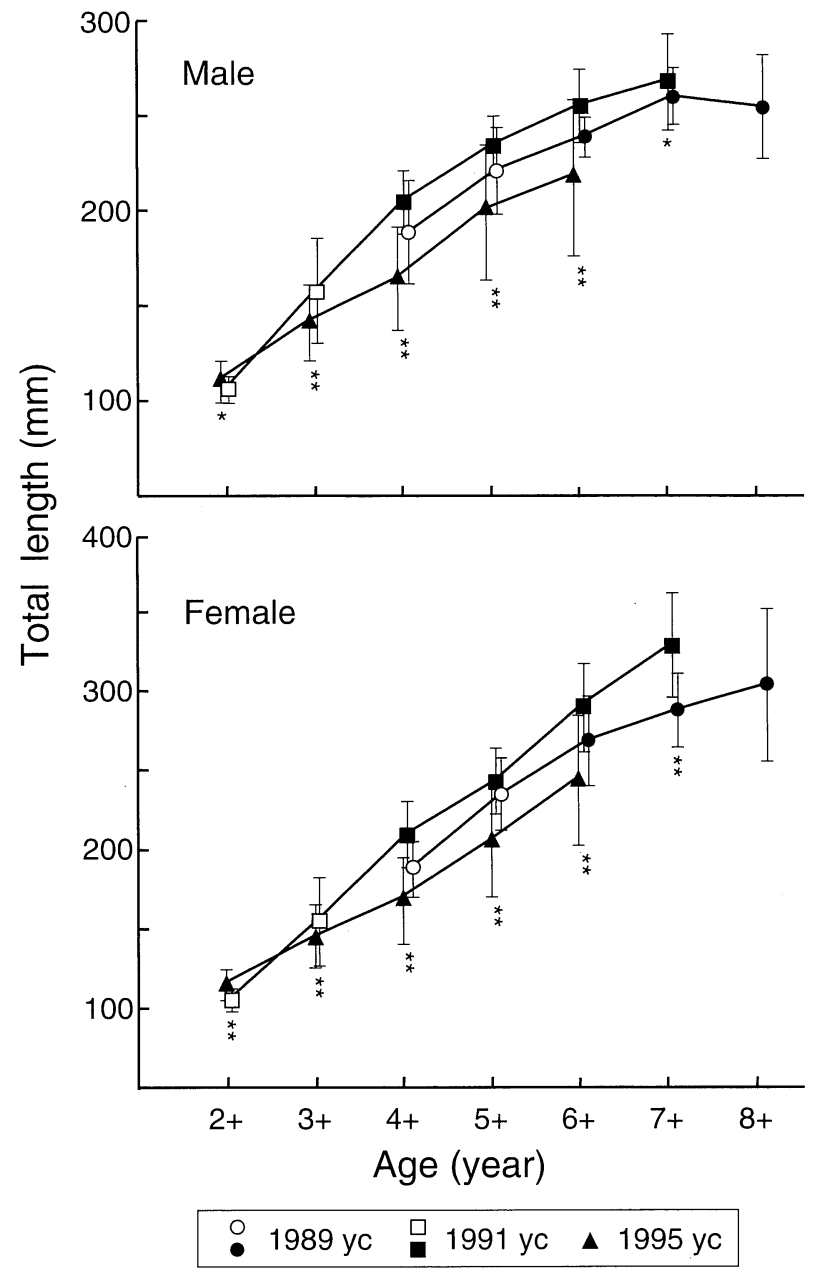

Fig. 2 Mean $( \pm S D)$ total lengths at each age of the three year-classes (1989, 1991 and 1995) of Hippoglossoides dubius. Open and closed marks indicate before and after hypoxic event in 1995, respectively. ${ }^{*} P<0.05$; ${ }^{* *} P<0.01$. Sample size for each data is $\geq 16$.

Ophiura spp. was high off Mori (Stn 29 and nearby waters) and generally was low in the central part of the bay. The abundance of Ophiura spp. differed significantly by station $(P<0.05)$, while the differences among months was not significant $(P=0.13)$. The highest abundance was 621 individuals (ind.) / $100 \mathrm{~m}^{2}$ in June 2000,1296 ind./ $100 \mathrm{~m}^{2}$ in OctoberNovember 2000 and 1372 ind./ $100 \mathrm{~m}^{2}$ in May 2001. In contrast, the abundance of P.japonica and natant decapods was not low in the central part of the bay. The abundance of P. japonica and natant decapods was not significantly different among stations $(P=0.30, P=0.41)$ or months $(P=0.69$, $P=0.92)$. The highest abundance of $P$. japonica was 55 ind. $/ 100 \mathrm{~m}^{2}$ in June 2000,84 ind. $/ 100 \mathrm{~m}^{2}$ in October-November 2000 and 140 ind. $/ 100 \mathrm{~m}^{2}$ in May 2001. The highest abundance of natant

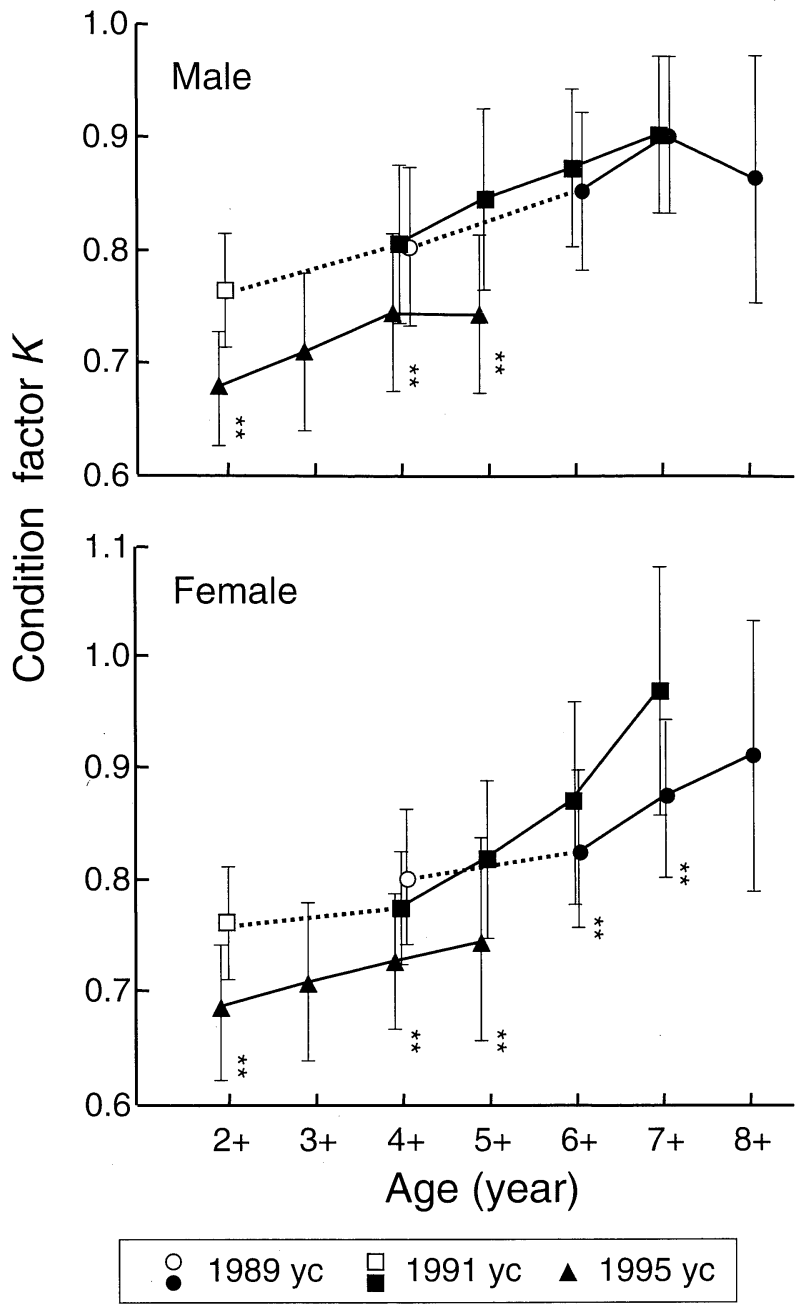

Fig. 3 Mean $( \pm S D)$ condition factors at each age of the three year-classes (1989, 1991 and 1995) of Hippoglossoides dubius. Open and closed marks indicate before and after hypoxic event in 1995 , respectively. ${ }^{*} P<0.05$; ${ }^{* *} P<0.01$. Sample size for each data is $\geq 16$.

decapods was $68 \mathrm{ind} . / 100 \mathrm{~m}^{2}$ in June 2000, 67 ind. $/ 100 \mathrm{~m}^{2}$ in October-November 2000 and 185 ind. $/ 100 \mathrm{~m}^{2}$ in May 2001.

\section{DISCUSSION}

The abundance of H. dubius in Funka Bay fluctuates remarkably among year-classes, and in recent years three dominant year-classes (1989, 1991 and 1995) occurred. ${ }^{36}$ Of these three year-classes, the fish born in 1995 when severe hypoxic water occurred were smallest in total length (Fig. 2) and lowest in condition factor (Fig. 3). The average size of American plaice Hippoglossoides platessoides in 
Grand Bank became smaller when the fish abundance increased. ${ }^{44}$ In the present study, however, the catch per unit effort (CPUE: the number of fish per 15-min tow) of $H$. dubius in 1993-2000 did not vary widely. Namely, the mean CPUE $( \pm S D)$ in the central part of the bay and nearby waters from late August to early September was less variable, ranging from $126.8 \pm 73.1$ fish/tow in 1998 to $236.7 \pm 208.4$ fish/tow in 1993, except for 1995 $(81.7 \pm 126.1 \mathrm{fish} /$ tow $) .^{28}$ In addition, the total length at age 2 of the 1995 year-class was larger than that of the other year-class (1991; Fig. 2). From these facts, it cannot be considered that the tardy growth of the 1995 year-class is due to the high population density of $H$. dubius.

According to Yokoyama et al. the H.dubius in Funka Bay consumed chiefly ophiuroids, fish, mysids and natant decapods in 1985-1986. In particular, ophiuroids were the most important prey for both the small- ( $\leq 200 \mathrm{~mm} \mathrm{TL})$ and largesized fish $(>200 \mathrm{~mm} \mathrm{TL})$ through the year. ${ }^{33,35} \mathrm{~A}$ similar situation was observed in 1982-1983. ${ }^{45}$ However, H.dubius in 2000-2001 fed chiefly on mysids, fish, natant decapods, T. japonica and $P$. japonica, and the relative importance of ophiuroids was very low except for fish of $\leq 200 \mathrm{~mm}$ TL in May 2001 (Fig. 4; Table 2). In south-east Kattegat, Sweden, hypoxia changed the food supply for Atlantic cod and plaice Pleuronectes platessa, and their principal prey changed from crustaceans and molluscus to polychaetes and ophiuroids (chiefly Amphiura filiformis). This dietary shift decreased the nutritional value of the food taken and decreased the average size of fish. ${ }^{21}$ It is known that A. filiformis have high tolerance to hypoxia. ${ }^{46}$ In the present study the principal prey of $H$.dubius changed from ophiuroids (a low energy content $)^{35}$ to crustaceans and bivalves (a high energy content) ${ }^{35,47}$ But the feeding intensity during the active feeding season (peak, MayJuly $^{31}$ ) in 2000-2001 was low compared with that in the 1980s. Namely, the proportion of H. dubius having a low $S C I(<0.5)$ from mid-May to August was approximately 50\% in 1985-1988 (sampling time: 10:00-15:00), ${ }^{31}$ while that in 2000-2001 were $65-77 \%$ for both sexes (Fig. 5). In addition, the mean SCI values in 2000-2001 (0.3-1.0, male; $0.8-0.9$, female) were low as compared with those in 1985-1988 (0.5-0.9, male; 0.7-1.6, female) ${ }^{31}$ Yokoyama reported that most of the Ophiura spp. consumed by $H$. dubius was $\leq 7 \mathrm{~mm}$ in disk dia-

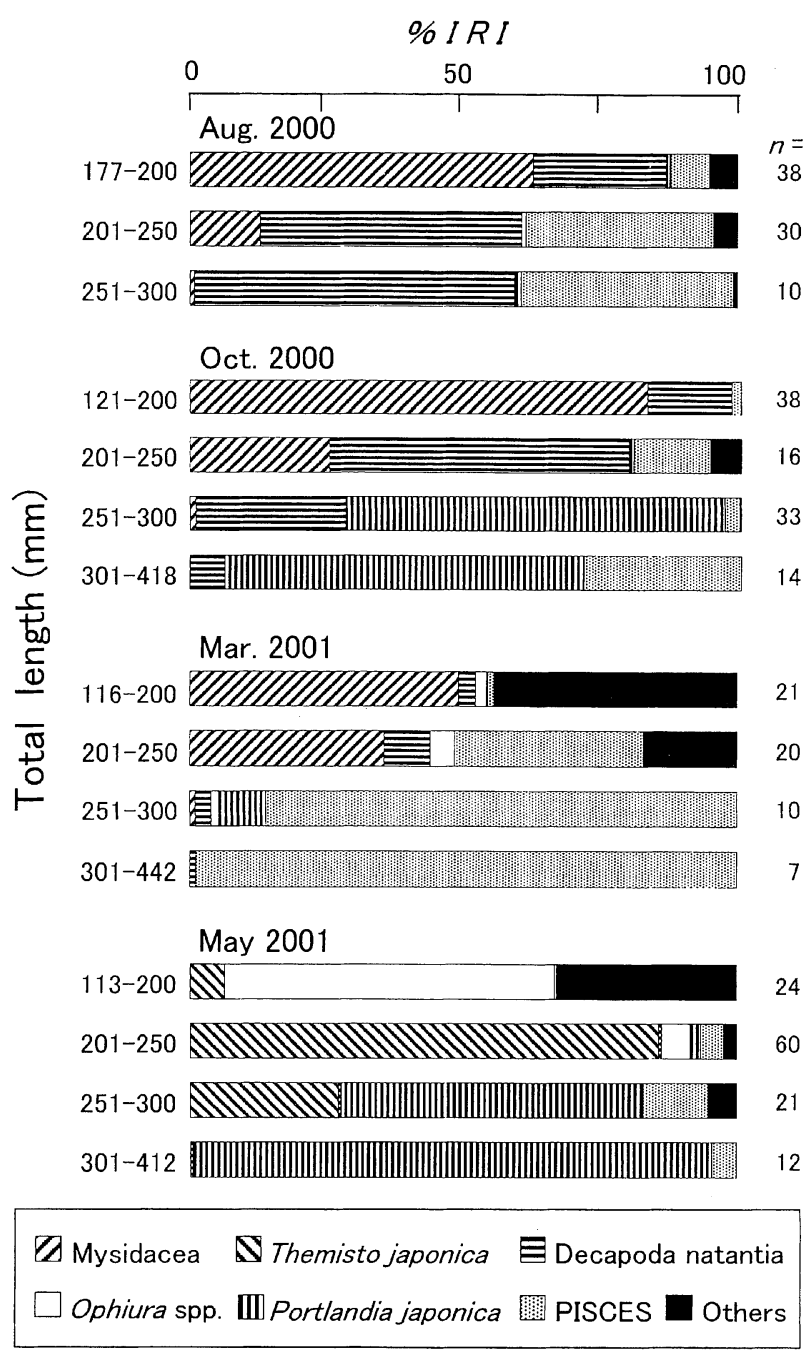

Fig. 4 Diet compositions of Hippoglossoides dubius, by size group of fish and month, expressed as percentage of index of relative importance (\%IRI) for prey items. $n$, number of stomachs examined.

Table 2 Comparisons of principal food of Hippoglossoides dubius in Funka Bay between 1985-1986 (Yokoyama et al..$^{33}$ ) and 2000-2001

\begin{tabular}{lll}
\hline Month & \multicolumn{1}{c}{ 1985-1986 } & \multicolumn{1}{c}{ 2000-2001 } \\
\hline July-Aug. & Ophiura spp. & Mysidacea, Decapoda natantia and Pisces \\
Oct.-Nov. & $\begin{array}{l}\text { Ophiura spp. and Pisces } \\
\text { Feb.-Mar. }\end{array}$ & $\begin{array}{l}\text { Mysidacea, Decapoda natantia and Portlandia japonica } \\
\text { Mysidacea and Pisces }\end{array}$ \\
May & $\begin{array}{l}\text { and Decapoda natantia } \\
\text { Ophiura spp. and Pisces }\end{array}$ & Ophiura spp., Themisto japonica and Portlandia japonica \\
\hline
\end{tabular}



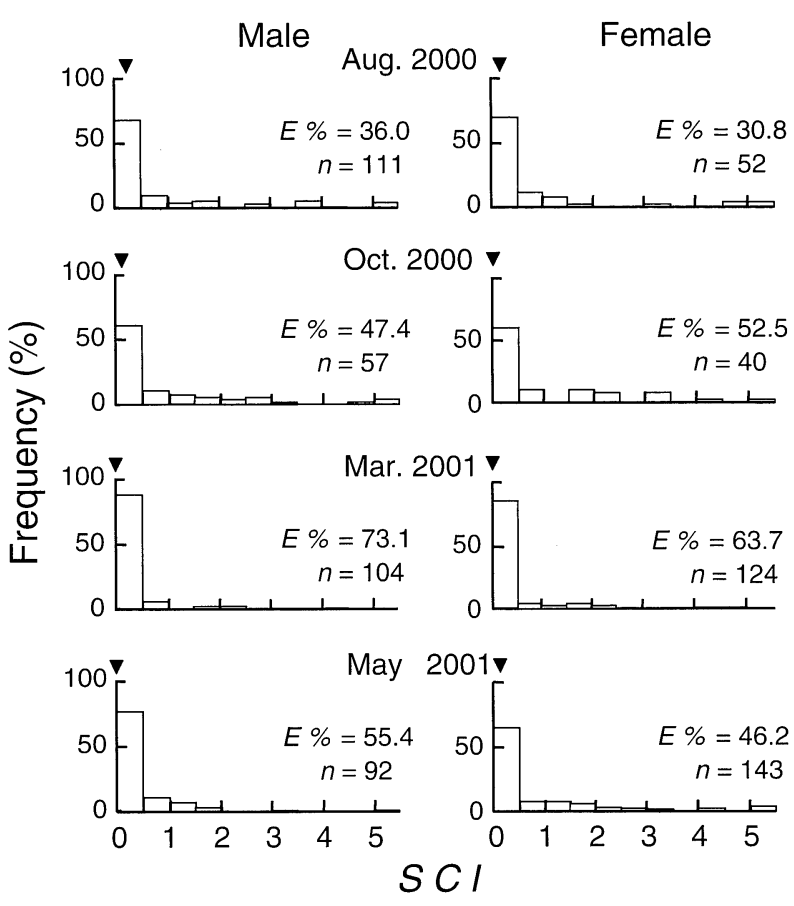

Fig. 5 Frequency distributions and medians $(\boldsymbol{\nabla})$ of stomach contents index (SCI) of Hippoglossoides dubius. $E \%$, percentage of empty stomachs; $n$, number of stomachs examined.

meter, and the abundance was high ( $>500$ ind./ $100 \mathrm{~m}^{2}$ ) at almost all of the stations ( $>50 \mathrm{~m}$ depth) in the bay through the year in 1985-1986. ${ }^{35}$ Although the data of ophiuroids in 2000-2001 contained all individuals collected, the abundance was very low in the central part of the bay, especially in June 2000 (Fig. 6). Therefore, it seems probable that the main factor of tardy growth of the 1995 year-class is the poor food intake caused by the reduction of prey abundance, particularly ophiuroids.

From August to November, the main habitat of $H$. dubius is formed in areas deeper than $80 \mathrm{~m} \mathrm{(4-}$ $9^{\circ} \mathrm{C}$ ) because of avoidance of high temperatures. ${ }^{30}$ The CPUE of H. dubius in the deeper area $(>90 \mathrm{~m})$ during hypoxia was low compared with that in the shallower area, and this situation was remarkable in $1995 .{ }^{28}$ Such a habitat shift to a high temperature area might have had an effect on the tardy growth of fish through the increase of the basal metabolism. However, it can be considered that the influence of water temperature was not large, judging from the facts that an apparent reduction in growth was not found in both the 1989 and 1991 yearclasses after the hypoxic period (Fig. 2). This is probably related to the fact that the duration of shift to the shallower area was not long. For example, in mid-October 1995 the CPUE of H.dubius was not low in the central part of the bay and nearby waters ( $353.3 \pm 150.1$ fish/tow) ${ }^{28}$

The total length of the 1995 year-class was larger than that of the 1991 year-class at age 2 (Fig. 2), indicating that the feeding activity of $0-1-$ year-old fish was hardly influenced by the reduction of ophiuroids. The reason for this is that the $0-1$-year-old H. dubius in the bay feeds on chiefly demersal plankton such as Microcalanus pygmaeus or mysids including Archaeomysis sp. (Kimura M, unpubl. data, 2003), and the majority of 0-1-year-old fish were not distributed in the central part of the bay and nearby waters. ${ }^{28}$ The low condition factor at age 2 of the 1995 year-class (Fig. 3) is probably related to a dietary change from demersal plankton to benthos including ophiuroids in addition to habitat shift to the central part of the bay. As aforementioned, an apparent reduction of growth was not found in both the 1989 and 1991 year-classes after the hypoxic event in 1995. Although there is no available information on the diets of H.dubius in the 1990s, the majority of fish of the two aforementioned yearclasses grew up to $200 \mathrm{~mm}$ TL or more at the hypoxic event (Fig. 2), and thereby probably consumed mainly fish such as young walleye pollock that were predominant in the bay. ${ }^{48}$ Similarly, the reduction of growth was not found in the 1995 year-classes after age 5, although the condition factors were low (Figs 2,3). This indicates that the reduced abundance of benthic animals (chiefly ophiuroids) strongly affected the 2-4year-old fish.

It is known that the abundances of ophiuroids and most of the crustaceans, gastropods and bivalves decrease drastically in hypoxic events. For example, in Amakusa-Tomoe Bay ophiuroids and sea urchin Echinocardium cordatum disappeared, and the number of species of bivalves and gastropods decreased. ${ }^{17}$ Also, in Hiuchi Nada on the Seto Inland Sea, crustaceans such as gammarids decreased in the number of species and abundance. ${ }^{16} \mathrm{~A}$ similar fact was also reported from Tokyo Bay: Crangon affinis and Ophiura kinbergi were not collected under oxygen concentration $\leq 1 \mathrm{mg} / \mathrm{L} \quad(\sim 0.7 \mathrm{~mL} / \mathrm{L}){ }^{20}$ Maita and Yanada reported that bottom water with oxygen concentration $\leq 2.0 \mathrm{~mL} / \mathrm{L}$ did not occur in the bay from 1998 to 2001 (Table 3). ${ }^{49-51}$ However, the abundance of ophiuroids was still low in 20002001, except for off Mori (Fig. 6). Most ophiuroids continue to grow for periods of 8 years at least, and probably for 10 or 15 years, and $O$. sarsi barely reach half their maximum size over a $2-4$-year period. ${ }^{52}$ It seems likely that the tardy recovery of ophiuroid abundance in the bay is related to their long life cycle. 
Fig. 6 Spacial distributions of Ophiura spp., Portlandia japonica and natant decapods collected with a sledge net.

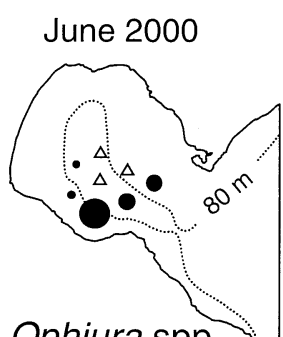

Ophiura spp.
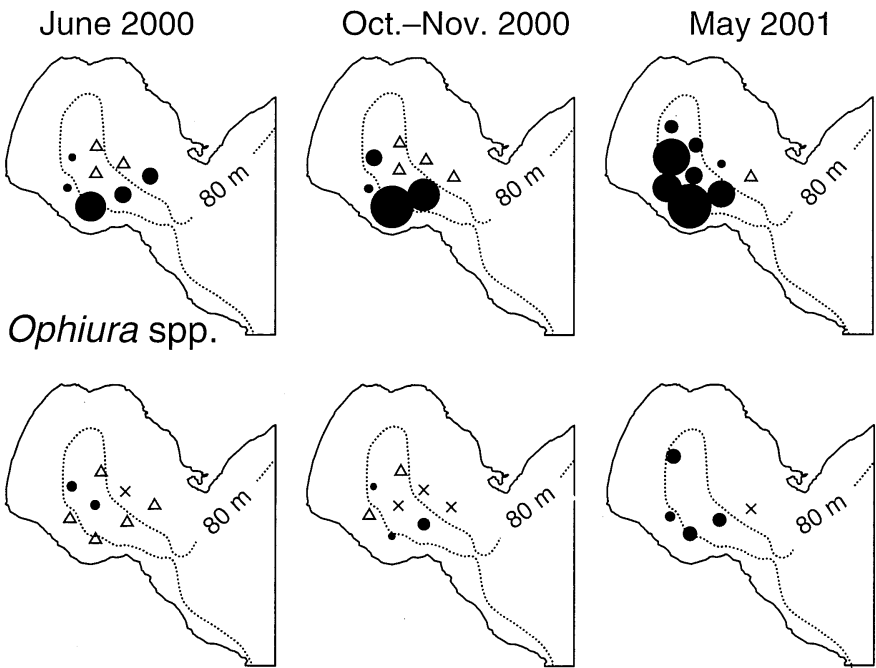

Abundance (inds. $/ 100 \mathrm{~m}^{2}$ )

$\boldsymbol{x}: 0$

$\Delta: \leq 10$

- : 30

- : 100

: 300

: 1000

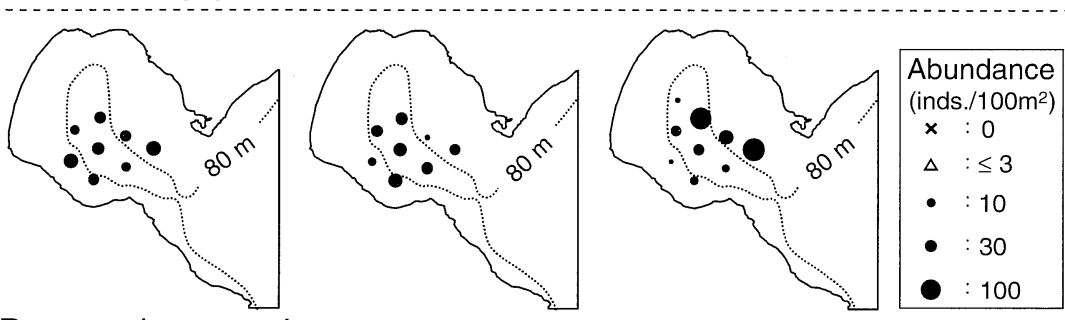

Decapoda natantia

Table 3 Dissolved oxygen concentration (DO) near the bottom in the central part of Funka Bay

\begin{tabular}{lccl}
\hline Date & Station no. & DO $(\mathrm{mL} / \mathrm{L})^{\dagger}$ & \multicolumn{1}{c}{ Source } \\
\hline 24 July 1995 & 30 & 0.58 & Maita $^{49}$ \\
23 Aug. 1996 & 30 & 0.91 & Maita $^{49}$ \\
4 Oct. 1997 & 30 & 1.07 & Maita $^{50}$ \\
28 Aug. 1998 & 30 & 2.67 & Maita $^{50}$ \\
29 Sep. 1999 & 30 & 3.29 & Maita $^{50}$ \\
23 Aug. 2000 & 33 & 2.52 & Present study $_{\text {27 Aug. 2001 }}^{33}$ \\
\hline
\end{tabular}

${ }^{\dagger}$ Lowest values observed in each year are shown.

\section{ACKNOWLEGMENTS}

We would like to thank the captain and crew of the R/V Ushio-Maru for their help with data collection. We also thank T Sekigawa, A Satou, Y Suzuki, H Izumiura and Y Tanaka (Hokkaido University) for their cooperation during the field surveys and data processing. The present study was supported, in part, by The Hokusui Society Foundation.

\section{REFERENCES}

1. Diaz RJ, Rosenberg R. Marine benthic hypoxia: a review of its ecological effects and the behavioural responses of benthic macrofauna. Oceanogr. Mar. Biol. Annu. Rev 1995; 33: $245-303$.

2. Rossignol-Strick M. A marine anoxic event on the Brittany coast, July, 1982. J. Coast. Res. 1985; 1: 11-20.

3. Gray JS, Wu RS, Or YY. Effects of hypoxia and organic enrichment on the coastal marine environment. Mar. Ecol. Prog. Ser. 2002; 238: 249-279.

4. Vetter RAH, Franke HD, Buchholz F. Habitat-related differences in the response to oxygen deficiencies in Idotea baltic and Idotea emarginata (Isopoda, Crustacea). J. Exp. Mar. Biol. Ecol. 1999; 239: 259-272.

5. Chabot D, Dutil J. Reduced growth of Atlantic cod in nonlethal hypoxic conditions. J. Fish Biol. 1999; 55: 472-491.

6. Chew SF, Ip YK. Biochemical adaptations of the mudskipper Boleophthalmus boddaerti to a lack of oxygen. Mar. Biol. 1992; 112: 567-571.

7. Low WP, Peng KW, Phuan SK, Lee CY, Ip YK. A comparative study on the responses of the gills of two mudskippers to hypoxia and anoxia. J. Comp. Phisiol. B 1993; 163: 487494.

8. via Dalla J, van den Thillart G, Cattani O, de Zwaan A. Influence of long-term hypoxia exposure on the energy metabolism of Solea solea. II. Intermediary metabolism in blood, liver and muscle. Mar. Ecol. Prog. Ser. 1994; 111: 17-27.

9. via Dalla J, van den Thillart G, Cattani O, Cortesi P. Environmental versus functional hypoxia/anoxia in sole Solea solea: the lactate paradox revisited. Mar. Ecol. Prog. Ser. 1997; 154: 79-90.

10. Nilsson HC, Skold M. Arm regeneration and spawning in the brittle star Amphiura filiformis (Müller OF) during hypoxia. J. Exp. Mar. Biol. Ecol. 1996; 199: 193-206. 
11. Nilsson HC. Effects of hypoxia and organic enrichment on growth of the brittle star Amphiura filiformis (Müller OF) and Amphiura chiajei Forbes. J. Exp. Mar. Biol. Ecol. 1999; 237: 11-30.

12. Baker MS, Mann R. Description of metamorphic phases in the oyster Crassostrea virginica and effects of hypoxia on metamorphosis. Mar. Ecol. Prog. Ser. 1994; 104: 91-99.

13. Wang WX, Widdows J. Physiological responses of mussel larvae Mytilus edulis to environmental hypoxia and anoxia. Mar. Ecol. Prog. Ser. 1991; 70: 223-236.

14. Rosas C, Martinez E, Gaxiola G, Brito R, Sanchez A, Soto LA. The effect of dissolved oxygen and salinity on oxygen consumption, ammonia excretion and osmotic pressure of Penaeus setiferus (Linnaeus) juveniles. J. Exp. Mar. Biol. Ecol. 1999; 234: 41-57.

15. Forbes TL, Lopez GR. The effect of food concentration, body size, and environmental oxygen tension on the growth of the deposit-feeding polychaete, Capitella species 1. Limnol. Oceanogr. 1990; 35: 1535-1544.

16. Imabayashi $\mathrm{H}$. Effects of oxygen-deficient water on the benthic communities. Nippon Suisan Gakkaishi 1983; 49: $7-15$.

17. Kikuchi T. Eutrophication in the sea area and indicators of benthic animals. In: The Japanese Society of Scientific Fisheries (ed.). Eutrophication and Biological Indicators in Coastal Waters. Kouseisha Kouseikaku, Tokyo. 1982; 84-100.

18. Pearson TH, Josefson AB, Rosenberg R. Petersen's stations revisited. I. Is the Kattegat becoming eutrophic? J. Exp. Mar. Biol. Ecol. 1985; 92: 157-206.

19. Josefson $A B$, Widbom B. Differential response of benthic macrofauna and meiofauna to hypoxia in the Gullmar Fjord basin. Mar. Biol. 1988; 100: 31-40.

20. Furota T. Survival and population maintenance of macrobenthic animals in inner Tokyo Bay. Bull. Coast. Oceanogr. 1991; 28: 160-169.

21. Pihl L. Changes in the diet of demersal fish due to eutrophication-induced hypoxia in the Kattegat, Sweden. Can. J. Fish. Aquat. Sci. 1994; 51: 321-336.

22. Pihl L, Baden SP, Diaz RJ. Effects of periodic hypoxia on distribution of demersal fish and crustaceans. Mar. Biol. 1991; 108: 349-360.

23. Pihl L, Baden SP, Diaz RJ, Schaffher LC. Hypoxia-induced structural changes in the diet of bottom-feeding fish and crustacea. Mar. Biol. 1992; 112: 349-361.

24. Baden SP, Loo L-O, Pihl L, Rosenberg R. Effects of eutrophication on benthic communities including fish: Swedish west coast. Ambio 1990; 19: 113-122.

25. Maita Y. The ecosystem and behavior of the nutrient element in Funka Bay, Hokkaido. Bull.Jpn. Soc. Fish. Oceanogr. 1980; 37: 33-36.

26. Maita Y, Yanada M. Funka Bay III Chemistry. In: Coastal Oceanography Research Committee, The Oceanographical Society of Japan (ed.). Coastal Oceanography of Japanese Islands. Tokai University Press, Tokyo. 1985; 113-125.

27. Maita Y. [On the hypoxic events during summer in Funka Bay, Hokkaido]. Suisan Gakujutsu Kenkyuu Kairyou Hojo Jigyou Houkoku (Annual Report of Fisheries Study published by The Hokusui Society Foundation). The Hokusui Society Foundation, Sapporo. 1998; 31-44 (in Japanese).

28. Maeda T, Nakatani T, Takatsu T. [Studies on oceanographic conditions, and distribution and fluctuation in stocks of flathead flounder Hippoglossoides dubius and coonstripe shrimp Pandalus hypsinotus in Funka Bay, Hokkaido.] Suisan Gakujutsu Kenkyuu Kairyou Hojo Jigyou Houkoku. The Hokusui Society Foundation, Sapporo. 2001; 37-57 (in Japanese).

29. Hayashi K. Hippoglossoides dubius in Funka Bay, Hokkaido. J. Hokkaido Fish. Exp. Stn 1963; 20: 6-15.

30. Yokoyama S, Maeda T, Nakatani T, Takahashi T, Matsushima H. Distribution and migration of Hippoglossoides dubius in Funka Bay and its offshore waters, Hokkaido. Bull. Jpn. Soc. Fish. Oceanogr. 1990; 54: 373-380.

31. Yokoyama S, Maeda T, Takahashi T, Nakatani T, Matsushima H. Annual life cycle of adult Hippoglossoides dubius in Funka Bay, Hokkaido. Nippon Suisan Gakkaishi 1991; 57: 1469-1476.

32. Hayase H, Hamai I. Studies on feeding habits of three flatfishes, Cleisthenes pinetorum herzensteini (Schmidt), Hippoglossoides dubius (Schmidt) and Glyptocephalus stelleri (Schmidt). Bull. Fac. Hokkaido Univ. 1974; 25: 82-99.

33. Yokoyama S, Maeda T, Nakatani T. Diet composition of Hippoglossoides dubius and distribution of megalobenthos in Funka Bay and its offshore waters, Hokkaido. Nippon Suisan Gakkaishi 1994; 60: 719-726.

34. Nakatani T, Koizumi H, Yokoyama S, Maeda T, Takahashi T, Matsushima $\mathrm{H}$. Age and growth of Pleuronectid flounder Hippoglossoides dubius in Funka Bay, Hokkaido. Nippon Suisan Gakkaishi 1990; 56: 893-901.

35. Yokoyama S. Ecological study on distribution and feeding of Hippoglossoides dubius in Funka Bay and its offshore waters, Hokkaido. PhD Thesis. Hokkaido University, Hakodate, 1992.

36. Nakatani T, Maeda T, Sugimoto K, Takatsu T, Takahashi T. Possible causes of annual change in the year class strength of flathead flounder Hippoglossoides dubius (Pisces, Pleuronectiformes) in Funka Bay, Hokkaido. Bull.Jpn. Soc. Fish. Oceanogr. 2002; 66: 216-223.

37. Ohtani K, Akiba Y. Studies on the change of hydrographic conditions in the Funka Bay I. The annual change of the water of the bay. Bull. Fac. Fish. Hokkaido Univ. 1970; 20: 303-312.

38. Ohtani K. Studies on the change of hydrographic conditions in the Funka Bay II. Characteristics of the waters occupying the Funka Bay. Bull. Fac. Fish. Hokkaido Univ. 1971; 22: 5866.

39. Ohtani K, Kido K. Oceanographic structure in Funka Bay. Mem. Fac. Fish. Hokkaido Univ. 1980; 31: 84-114.

40. Ohshima K, Yokota S. Oceanographic description of the coast of Japan XXV. Funka Bay (IV): geology and geography. Bull. Coast. Oceanogr. 1983; 20: 189-203.

41. Maita Y, Nakao S. Studies on environmental conditions of cultivated scallop Patinopecten yessoensis in Funka Bay, Hokkaido. Suisan Gakujutsu Kenkyuu Kairyou Hojo Jigyou Houkoku (Annual Report of Fisheries Study published by The Hokusui Society Foundation). The Hokusui Society Foundation, Sapporo. 1996; 17-25 (in Japanese).

42. Pinkas L, Oliphant MS, Iverson ILK. Food habits of albacore, bluefin tuna and bonito in California waters. Fish. Bull. 1971; 152: 1-105.

43. Cortés E. A critical review of methods of studying fish feeding based on analysis of stomach contents: Application to elasmobranch fishes. Can. J. Fish. Aquat. Sci. 1997; 54: 726-738.

44. Pitt TK. Changes in abundance and certain biological characteristics of Grand Bank American plaice, Hippoglos- 
soides platessoides. J. Fish. Res. Board Can 1975; 32: 13831398.

45. Yokoyama S. Studies on distribution of benthic animals and food habits of Hippoglossoides dubius Schmidt and Glyptocephalus Stelleri (Schmidt) in Funka Bay and adjacent waters, Hokkaido. MS Thesis, Hokkaido University, Hakodate, 1985.

46. Vistisen B, Vismann B. Tolerance to low oxygen and sulfide in Amphiura filiformis and Ophiura albida (Echinodermata: Ophiuroidea). Mar. Biol. 1997; 128: 241-246.

47. Brey T, Rumohr H, Ankar S. Energy content of macrobenthic invertebrates: general conversion factors from weight to energy. J. Exp. Mar. Biol. Ecol. 1988; 117: 271-278.

48. Yokoyama S, Maeda T, Takahashi T, Nakatani T, Matushima H. Temporal and spatial distributions of demersal fish in Funka Bay and offshore, Hokkaido. Mem. Fac. Fish. Hokkaido Univ. 1989; 40: 8-21.

49. Maita Y. Time series changes of dissolved oxygen and lipid composition in bottom sediments in Funka Bay, Hokkaido.
Suisan Gakujutsu Kenkyuu Kairyou Hojo Jigyou Houkoku (Annual Report of Fisheries Study published by The Hokusui Society Foundation). The Hokusui Society Foundation, Sapporo. 1997; 19-26 (in Japanese).

50. Maita Y. Studies on sinking particles and sediments for clarifying the origin of hypoxia in Funka Bay, Hokkaido. Suisan Gakujutsu Kenkyuu Kairyou Hojo Jigyou Houkoku (Annual Report of Fisheries Study published by The Hokusui Society Foundation). The Hokusui Society Foundation, Sapporo. 2000; 34-45 (in Japanese).

51. Yanada M. Contribution of accumulation process of organic matters to hypoxia in bottom water in Funka Bay, Hokkaido. Suisan Gakujutsu Kenkyuu Kairyou Hojo Jigyou Houkoku (Annual Report of Fisheries Study published by The Hokusui Society Foundation). The Hokusui Society Foundation, Sapporo. 2002, 3-10 (in Japanese).

52. Fell HB. The ecology of ophiuroids. In: Boolootian RA (ed). Physiology of Echinodermata. Interscience Publishers, New York. 1966; 129-143. 